\title{
SOCIO-ECONOMIC FACTORS INFLUENCING AGRICULTURAL RADIO PROGRAMME FILIN MAINOMA IN KAINJI AREA OF NIGER STATE, NIGERIA
}

AROWOLO, K. 0., ${ }^{*}$ *ABIONA, B. G., ${ }^{2}$ AWOTUNDE, J. M., ${ }^{3}$ and OLAOYE, A. A. ${ }^{1}$

\author{
http://dx.doi.org/10.4314/ejesm.v6i5.4
}

\section{Received 21st Januaru 2013; accepted 1st August 2013}

\begin{abstract}
The study examined socio economic factors influencing agricultural radio programme FILIN MAINOMA in Kainji Area of Niger State. Multi-stage sampling technique was used to select 252 respondents from the study area. Data collected were analyzed using descriptive and inferential statistics such as, Pearson Product Moment Correlation Coefficient (PPMC) and Chi-Square analysis $\left(\chi^{2}\right)$. Results showed that the mean age of the respondents was 25.50 years while majority (96.60\%) was male. Also $63.10 \%$ had no formal education while $22.70 \%$ had primary school education. Furthermore, most (93.70\%) were married, 97.20\% were Muslims and $99.20 \%$ engaged in full-time fishing. Mean years of fishing experience was 15.50 years and $65.90 \%$ were members of fish farmers' organization. The average household size was 4 persons. Majority (99.20\%) of the respondents was aware of and listened to the radio programme FILIN MAINOMA. Also, correlation analysis results revealed a significant and positive relationship between the household size $(r=0.21, p<0.05)$, and year of membership association $(r=0.24, p<0.05)$, constraint on fishing practices $(r=0.13, p<0.05)$ and respondents' perception of the radio programme. The study concluded that FILIN MAINOMA had impact on fisherfolks cash per unit effort. The study recommended that the programme should be strengthened and sustained while other similar programmes can be initiated in other radio stations in the area.
\end{abstract}

Key words: Constraint, socio economics factors and perception

\section{Introduction}

In the past, information on agricultural production was disseminated to rural farmers, and fisherfolks by means of oral message, print media, posters and electro media i.e. (radio and television). The radio had played a vital role in sustainable development; this is widely acknowledged especially in some rural areas. Deliberate plan and efforts at maximizing this role is treated with levity. (Okigbo, 1998). Over the years, deliberate efforts have been made by donors and African countries to bring about agricultural development without much to show for it. Information is an essential ingredient in agricultural development programs but Nigerian farmers seldom feel the impact of agricultural innovative idea because they have no access to vital information or because it is poorly disseminated (Ozowa, 1995).

People have used radio as a medium for disseminating information because of its reach and popularity. Through radio, the most remote populations can learn about their environment and contributions they can make to sustain it (Nyirenda, 1981). As a result of the changing

${ }^{I}$ College of Fisheries and Freshwater water Aquaculture, Niger State, Nigeria

${ }^{2}$ Department of Agricultural Administration, Federal University of Agriculture Abeokuta

${ }^{3}$ Department of Agricultural Extension and Rural Development,

Federal University of Agriculture Abeokuta, P. M. B. 2240

*Corresponding author: kehindearowolo@yahoo.com democratic climate in Africa and in 1990s, government passed legislations to allow more independent management of radio stations, increasing not only the potential of freedom of information and expression but also the opportunities for using radio as an instrument to promote environmental awareness. Based on this background the study has the following specific objectives to:

1. describe the socio economic characteristics of respondents in the study area

2. determine the frequency and listening pattern of fisherfolks to "filin Mainoma" agricultural radio programme.

3. identify general problem encountered by fisherfolks.

Information is an essential ingredient in agricultural development programs but Nigerian farmers seldom feel the impact of agricultural innovative idea because they have no access to vital information or because it is poorly disseminated (Ozowa, 1995). One of the constraints facing the use of the radio in the kainji Lake area is poor reception and quality of the radio programmes especially for areas further from the booster station. This made information available to the fishermen to be scanty or not 
available. Most of the editors also lacked the skills of how to write script on agricultural information; even when the information is relevant; it's seldom aired at the proper time and so does not get to the fisherfolks.

The mass media is extensively used in Nigeria to disseminate important information. The urban areas are usually the target of such dissemination method due to their consumption nature. In recent years however, mass media (especially electronic medium) has been used as a means of disseminating specific information to specific groups of people, such as production message to farmers. The use of mass media is favoured when the economic and accessibility difficulties associated with person-to-person contact is considered. In the light of this, there is a need to assess fisherfolk's perception on effectiveness of radio programme.

\section{Hypotheses of the Study}

$\mathrm{Ho}_{1}$ :- there is no significant relationship between the respondents' socio economic characteristic and their perception of the radio programme.

$\mathrm{Ho}_{2}$ :- There is no significant relationship between constraints faced by fisherfolks' perception of radio programme effectiveness.

\section{Study Area}

Kainji Lake is located in the north-western part of Nigeria. The Lake is approximately $120 \mathrm{~km}$ long with a surface area of approximately $1270 \mathrm{~km}^{2}$ (Ita, 1982). The Kainji Lake has about 5000 fisherfolks. According to Du feu (2001), the whole Lake has about 286 fishing localities (villages and camps) spread along the shoreline and Island of Kainji Lake. It lies between latitude $9^{0} 50^{1}-10^{0} 55 \mathrm{~N}$ and longitude $4^{0} 45 \mathrm{E}$.

\section{Materials and Methods}

\section{Sampling Technique and Sample Size}

Multi-stage sampling technique was used in this study. Information in form of data needed for the study was provided by the randomly selected respondents. The Kainji Lake area of Northern Nigeria has been demarcated into three (3) main strata by Nigeria /German Kainji Lake fisher promotion project and updated in 2004 (Abiodun and Nworu 2004). Main strata 1 and 2 are located in Niger State while main stratum 3 is located in Kebbi State. This study was limited to strata 1 and 2 in Niger State. There are six sub-strata in both main strata (two in main stratum 1 and four in main stratum 2).

Stage 1: Two main strata that fall within Niger State were selected i.e. main strata 1 and 2
Stage 2: $50 \%$ of each selected main strata were selected.

Main Stratum 1(2substrata) - 1 substratum selected

Main Stratum 2 (4substrata) - 2 substrata selected

Stage 3: $20 \%$ of total number of fishing villages from each selected substratum were selected making a total number of 18 villages.

Stage 4: $20 \%$ of the respondents were selected randomly from total numbers of respondents from each substratum, giving a total number of two hundred and fifty six (256) fisherfolks, which were selected from the 18 villages which make the sample size of the study but the analysis were based on two hundred and fifty two (252) respondents.

Primary data for the study was collected using well-structured interview guide, variables were subjected to face validity. A reliability coefficient of 0.75 was obtained, using test retest method. Analyses of data involved descriptive tools such as frequency counts and percentage scores

\section{Data Analysis}

The data collected were subjected to descriptive statistics (means, percentage and frequency distribution); inferential statistics such as Chi Square and Pearson Product Moment Correlation (PPMC) were used to test the stated hypotheses.

\section{Result and Discussions \\ Socio-Economic Characteristics of the Respondents}

The mean age of the respondents was 25.50 years, $(\mathrm{SD}=1.45)$ indicating that majority $(68.30 \%)$ of the respondents were above 25 years old which implies that majority of the respondents were within the economically active age category (FAO, 1997). Respondents in this age range are more innovative motivated and adaptable individuals who can with wisdom cope with farming and fishing challenges (Fakoya and Daramola 2005)

Results further showed that majority $(97.60 \%)$ of the respondents were male. This is supported by (Abiona, 2010) that fishery activities are mostly dominated by men. Considering the educational status of the fisherfolks in the study area, it was revealed that more than half $(63.10 \%)$ of the respondents had no formal education and $(22.70 \%)$ had primary education. This implies that the rural artisanal 
fisherfolks do not have access to adult education or formal education.

Also, majority $(97.20 \%)$ of the fisherfolks were Muslims while $(2.00 \%$ and $5.00 \%)$ were Christian and traditional worshippers respectively. This result supports the fact that the northern part of the Nigeria is occupied predominantly by Muslims WHO, (2001). Also, half $(50.00 \%)$ of the fisherfolks had household size of 5-10 persons, less than one quarter(23.80\%) of fisherfolks had above 16 household members. This result shows that fisherfolks had more people to cater for and more hands to employ in their fishing activities to earn income for the household. Majority $(93.70 \%)$ of the respondents were married, while few $(6.30 \%)$ were single. This finding showed that marriage remains a valued culture in the study area. This result was confirmed by the reports of Fakoya, (2000) and Oladoja et al. (2008) that marriage is a means of bringing up children or continuation of family name, Ekong, (2003) pointed out that marriage in our society is highly cherished.

Experience played prominent role in any farming enterprise. From the finding of this study, less than half $(46.40 \%)$ of the respondents had more than ten years of fishing experience while less than one third $(31.00 \%)$ had $1-5$ years' experience. The experience of the respondents in fishing activity was sufficient for a thorough understanding of the technical procedures involved in fishing and for acquiring information in their fishing activity (Chamber, 1994).

Occupations remain valid in our society as people have one or two things they engage in which gives them a sense of belonging in our society (Abiona, 2010). Nearly all (99.20\%) of the respondents engaged in fishing activities while $0.80 \%$ engage in other occupations such as petty trading, for their livelihood activities.

The respondents' membership of social organizations was also explored. The importance of social group membership for this study came from the realization that groups are one possible avenue for mobilizing fisherfolks for collective action (Abiona, 2010). Also group can only serve as entry points for fisherfolks to adopt new innovations or receive new information that create awareness and bring change in behavior. Abiodun et. al (2002) had pointed out the importance of group networking in adoption of various technologies. Table 1 shows that twothird $(65.90 \%)$ of the respondents were members of fish farmers association while one third
$(22.22 \%)$ were members of fadama group an avenue for exchange of ideas on farmers problems. Membership of these organizations help the fisherfolks to obtain bulk purchase of inputs thereby reducing cost of production, regular updates on new innovation and opportunity for government agencies, input dealers and credit institution.(Basorun and Olakulehin 2007).

\section{Radio Agricultural Programme (filin Mainoma)}

The data in table 2 reveals that majority $(87.70 \%)$ of the respondents had radio. This in line with Ibeun and Mdaihli (1994) who reported that radio is generally accepted as the medium of communication among the fisherfolks in the Lake area. Also Agunga and Fishman (2004) also confirmed that radio remains the most reliable communication channel for reaching the rural farmers. Almost all $(99.20 \%)$ of the respondents had been aware of the radio programme.

The result also indicated that majority $(99.20 \%)$ of the respondents listened to radio agricultural programme "filin Mainoma" while very few $(0.80 \%)$ of the fisherfolks do not. This confirmed that rural radio programmes offers both the adequate reach and relevance to its listeners; It was also found that most (60.30\%) of the respondents had access to radio by ownership, while nearly a quarter $(23.00 \%)$ had access through the organization they belong to, this in line with finding of Baygen, (1996) that radio is a common household item throughout Africa and thus the invention of the crank radio, which eliminates the needs for batteries, further increased the ownership of radio.

Majority $(98.80 \%)$ of the respondents said that the message from the radio programme "filin Mainoma" was interesting which encourages them to listen to the programme. Also almost all $(98.00 \%)$ of the respondents said that they had perceived need for agricultural radio programme "filin Mainoma" this is in line with Jean, (2001) that new information can change the way of thinking, attitude and stimulates economic development through interesting programmes they broadcast to audience. It is worthy of note that majority $(97.60 \%)$ of the respondents said that the "filin Mainoma" radio programmes was very relevant to their fishing practices. This implies that information on production activities, current price, information on sales and timing which are relevant to the needs of fisherfolks are aired on the "filin Mainoma" radio programme. 
It was indicated that majority $(93.20 \%)$ of the respondents listened to radio agricultural program "filin Mainoma" regularly. The result of the finding further shows that majority $(79.40 \%)$ listened to "filin Mainoma" in the mornings before going for fishing. Concerning the hours spent on radio, the result shows that most $(67.10 \%)$ spent one hour either to listen to the programs, news or music. Data in table 2 revealed that more than one third ( $38.90 \%)$ of the respondents said that perceived relevant of the contents radio agricultural programmes "filin Mainoma" which contributes to their fishing activities aroused their interest, while a quarter $(26.90 \%)$ said that presentation format such as program format, discussion, questions and answer aroused their interest.

\section{General problems encountered by fisherfolks in their fishing activities and radio programmes.}

Table 3: It was revealed that almost $(89.70 \%)$ of the respondents reported stealing of their fishing gear and crafts by thieves on the lake. majority $(97.60 \%)$ complained that they were affected by conflict because of using Dalla net of small mesh size that harvest the smallest or juvenile fish from river or water body, this lead to total harvesting, that means nothing to harvest in nearest future by the fisherfolks and their family. Majority $(98.00 \%)$ of the respondents had the problems of high cost of fishing materials which was in line with Dada (2004) who claimed that another major constraint militating against artisanal fisheries in Kainji Lake include inadequate and high cost of fishing inputs as a result of high exchange rate of local currency and lack of access to credit facilities. Another major problem mentioned was over fishing by notables percentage of the respondents $(84.10 \%)$, and this was confirmed by Abiodun (2002) that fishing communities in Kainji Lake area are threatened by poverty because fisheries on the Lake was already over exploited.

Very few $(8.70 \%)$ of the respondents were affected by lack of social amenities (electricity and good roads). On problems encountered in relation to access and service of radio agricultural programme "filin Mainoma", few $(11.60 \%)$ of the respondents said that they had problems of language barrier and $6.00 \%$ of the respondents said that the programme was not detail enough. More than one third (34.90\%) said the programme was not in line with fishing practice, $(27.40 \%)$ of the respondents are affected by signal problems.
The result of the chi-square $\left(\chi^{2}\right)$ analysis shows that there is a association between the respondents' sex $\left(\chi^{2}=78.70, \quad \mathrm{p}<0.05\right)$ educational level $\left(\chi^{2}=2.41, \mathrm{p}<0.05\right)$, membership of associations $\left(\chi^{2}=1.31, \mathrm{p}<0.05\right)$ and major occupation $\left(\chi^{2}=40.90, p<0.05\right)$ and their perception towards radio programs. The study also revealed significant relationship between household size $(\mathrm{r}=0.21, \mathrm{p}<0.05)$ and year of membership of association $(\mathrm{r}=$ $0.24, \mathrm{p}<0.05$ ) and their perception. This observation is expected since fisherfolks acclaimed their ties with friends and neighbours as a source of information and a greater influence on the perception of radio agricultural programme; finding of Ajayi (2005).

From table 5 the study shows that respondents' constraints had significant relationship with fisherfolks perception of radio programme "filin Mainoma" at 0.05 level $(\mathrm{r}=$ $0.13, \mathrm{P}=0.05)$. Therefore, it can be concluded that the constraints facing the fisherfolk affected the perception of the radio programme "filin Mainoma". Thus, show challenges confronting an average fisherfolk in their perception of radio agricultural programmes "filin Mainoma", if this challenge can be removed, it will go a long way in improving their fishing practices.

\section{Conclusion and Recommendations}

It was concluded that attending of programme by the respondents had contributed to improvements of their catch per unit effort. This study therefore recommends as follows;

- That the programme should be transmitted regularly to serve as educational tools.

- The room must be given for participation of the fisherfolks to make them see the programme as theirs.

- Radio programme should be detailed enough, address fisherfolks needs and include other economic activities so as to help fisherfolks have other sources of income, especially during the dry season to prevent overfishing.

- The tentacles of the local radio stations should be spread to the local fishing communities not reached hitherto so that they can equally benefit from programme.

\section{References}

Abiodun J. A and Nworu, A.M. (2004), Fisheries Statistical Bulletin Kainji Lake. 
Nigeria Kainji Lake Fisheries Management and Conservation Unit (KLFMCU)

Abiodun, J.A (2002), Evaluation of fisheries catch trend on Lake Kainji, in Nigeria (19952001). Journal of Applied Science and Environmental Management. 7(2), 9-13.

Abiona, B. G. (2010), Comparative analysis of integrated and non-integrated fish farming In Ogun state, Nigeria.

Agunga, R and Fishman, A. K. (2004.), "Development support communication for community" Driven Development in Africans. Journal of Extension system. 32-44.

Basorun, Y. O and Olakulehin (2007), The Lagos state fish farmers "Association Report." LEISA magazine. Vol.23 (1) pg 1-3.

Baygen, T. (1996), Introductory literature on Wind-up Radio contained in the Technology Newsletters, South Africa. Review of Experiences in Development Countries" International Journal of Instructional media.

Buzigos, G. P. (1971), Frame Survey at Kainji Lake Statistical Study. FI:SF/N/Rm24. FAO.

Chambers, R. (1994), "Participatory rural appraisal, (PRA): Analysis of experience. World Development, 22(9), 125 3-68.

Dada, B. F. (2004), Contribution of fisheries to employment, National Economy and food security in Nigeria. Paper presented at the 2003 FISON public lecture Lagos. $22^{\text {nd }}$ December2003. Fish Network 1 (1) 1-6.

Ekong, E. E. (2003), An Introduction to Rural Sociology (2 ${ }^{\text {nd }}$ Edition).Uyo Nigeria Dove Educational Publishers.

Fakoya E. O.and Daramola B. G. (2005), Socioeconomic factors influencing farmers' particsipation in integrated fish farming (published) Rural Sociology Journal. Pp2.

Fakoya, E. O. (2000), Farmers use of sustainable land management practices in Ondo state, Nigeria. Unpublished Phd. Thesis, Department of Agricultural extension and Rural Department University of Ibadan. Pp160.
FAO, (1997), Review of the State of World Agriculture. FAO Fisheriesr.886 (Rev.1)

Girard, B. (2001) "The challenges of ICTs and rural radio' Paper presented at the first international workshop on farm radio broad casting, 19-22 February 2001, FAO, Rome Ibeun, M.O and Mdaihli, M (1994), Media of communication among fisher men around Kainji Lake Basin. Nigerian German Kainji Lake Fisheries Promotion Project Technical Report Series No.1, 42pp. ISBN 978 -037-000-5

Jean, P. I. (2001) The role and use of rural radio in Africa FAO (2003) paper.

Myers, M. (2000), 'Community radio \& development', in R. Fardon and G. Furniss (eds) (2000), African broadcast cultures: Radio in transition Harare. Zimbabwe. Baobab Publishing and Oxford: James Currey.

Nyirenda, J. E. (1981), "The role of Educational Radio in National Development: A review of Experiences in Developing countries" International Journal of Instructional Media (Vol. 8, No 3).

Okigbo, C. C. (1998), Unpublished classroom lectures on issues in International media, International Media, Fargo; North Dakota state university.

Oladoja, M. A. Adedoyin, S. E. \& Adeokun, O. A., (2008), Training needs of fisherfolks on fishing technology. Journal of food Agriculture and Environment science and technology.6:1 WFL publisher, Helsinki, Finland WWW. World food.Net.

Ozowa V. M. (1995), Quarterly Bulletin of the International Association of Agricultural Information Specialist, IAALD/CABI .40 .1, 1995

World Health Organisation. (2001), Nutrition for health and development (Available at www.WHO.org returned march 31, 2008. Pp 10-19. 
Socio Economic Factors Influencing Agricultural Radio Programme................AROWOLO et al.

Table1 Distribution of the Respondents According to their Socio economic characteristics $(\mathrm{N}=252)$

\begin{tabular}{|c|c|c|c|c|}
\hline Variables & Frequency & Percentage & Mean & Std. Dev. \\
\hline \multicolumn{5}{|l|}{ Age (Years) } \\
\hline Below 31 years & 80 & 31.70 & & \\
\hline $31-40$ & 64 & 25.40 & 25.50years & 1.45 \\
\hline $41-50$ & 37 & 14.70 & & \\
\hline $51-60$ & 30 & 11.90 & & \\
\hline 60 and above & 41 & 16.30 & & \\
\hline \multicolumn{5}{|l|}{ Sex } \\
\hline Male & 246 & 97.60 & & \\
\hline Female & 6 & 2.40 & & \\
\hline \multicolumn{5}{|l|}{ Educational status } \\
\hline No formal education & 159 & 63.10 & & \\
\hline Primary education & 57 & 22.70 & & \\
\hline Secondary education & 12 & 4.70 & & \\
\hline Others & 24 & 9.50 & & \\
\hline \multicolumn{5}{|l|}{ Religion } \\
\hline Christians & 2 & 0.80 & & \\
\hline Muslim & 245 & 97.20 & & \\
\hline Traditional & 5 & 2.00 & & \\
\hline House hold size & & & 4.00 & 2.50 \\
\hline Less than 4 & 11 & 4.36 & & \\
\hline $5-10$ & 126 & 50.00 & & \\
\hline $11-15$ & 55 & 21.83 & & \\
\hline Above 16 & 60 & 23.81 & & \\
\hline \multicolumn{5}{|l|}{ Marital status } \\
\hline Single & 16 & 6.30 & & \\
\hline Married & 236 & 93.70 & & \\
\hline Year of experience & & & 15.50 & 0.80 \\
\hline $1-5$ years & 78 & 31.00 & & \\
\hline $6-10$ years & 57 & 22.60 & & \\
\hline Above 10 years & 117 & 46.40 & & \\
\hline \multicolumn{5}{|c|}{$\begin{array}{l}\text { Social organization } \\
\text { membership }\end{array}$} \\
\hline Fadama group & 56 & 22.20 & & \\
\hline Young farmers & 30 & 11.90 & & \\
\hline Fish farmers & 116 & 65.90 & & \\
\hline
\end{tabular}


Table 2 Distribution of the Respondents According to their Access and Listenership to "Filin Mainoma" Radio Agricultural Programme

\begin{tabular}{|c|c|c|}
\hline Variables & Frequency & Percentage \\
\hline \multicolumn{3}{|l|}{ Have Radio } \\
\hline Yes & 221 & 87.70 \\
\hline No & 31 & 12.30 \\
\hline \multicolumn{3}{|c|}{ Listen to radio programme } \\
\hline Yes & 250 & 99.20 \\
\hline No & 2 & 0.80 \\
\hline \multicolumn{3}{|c|}{ Awarness of Radio Programme } \\
\hline Yes & 250 & 99.2 \\
\hline No & 2 & 0.80 \\
\hline \multicolumn{3}{|l|}{ Access to radio } \\
\hline By ownership & 152 & 60.30 \\
\hline Through neighbor & 36 & 14.30 \\
\hline Through organization & 58 & 23.00 \\
\hline Through relatives & 6 & 2.40 \\
\hline \multicolumn{3}{|l|}{ Interesting message } \\
\hline Yes & 249 & 98.80 \\
\hline No & 3 & 1.20 \\
\hline \multicolumn{3}{|c|}{ Perceived need for the programme } \\
\hline \multicolumn{3}{|c|}{ Yes } \\
\hline No & 248 & 98.40 \\
\hline & 4 & 1.60 \\
\hline \multicolumn{3}{|l|}{ How relevant } \\
\hline Very relevant & 246 & 97.60 \\
\hline Relevant & 4 & 1.60 \\
\hline Not relevant & 2 & 0.80 \\
\hline \multicolumn{3}{|c|}{ How often they listen to radio } \\
\hline Regularly & 235 & 93.20 \\
\hline Occasionally & 8 & 3.20 \\
\hline Rarely & 9 & 3.60 \\
\hline \multicolumn{3}{|l|}{ Time of the day } \\
\hline Morning & 200 & 79.40 \\
\hline Afternoon & 46 & 18.30 \\
\hline Evening & 6 & 2.30 \\
\hline \multicolumn{3}{|l|}{ Hour spent on radio } \\
\hline One hour & 169 & 67.10 \\
\hline Two hours & 36 & 14.30 \\
\hline More than 3 hours & 47 & 18.60 \\
\hline \multicolumn{3}{|c|}{ Area of interest in Radio programs } \\
\hline Advertisement & 45 & 17.90 \\
\hline \multicolumn{3}{|l|}{ Presentation Format } \\
\hline Relevant information & 68 & 26.90 \\
\hline \multicolumn{3}{|l|}{ Others (music) } \\
\hline \multirow[t]{3}{*}{ Not indicated } & 98 & 38.90 \\
\hline & 19 & 7.50 \\
\hline & 22 & 8.70 \\
\hline \multicolumn{3}{|c|}{$\begin{array}{l}\text { Radio stations in the area they listen to, both } \\
\text { (local and international) }\end{array}$} \\
\hline Radio koro & 136 & 54.00 \\
\hline Radio kaduna & 78 & 31.00 \\
\hline Radio kwara & 28 & 11.10 \\
\hline Hausa BBC & 10 & 3.90 \\
\hline
\end{tabular}


Table 3 General Problems Encountered by the Fisherfolks in their Fishing Activities and Radio Programs $(\mathrm{N}=252)$

\begin{tabular}{|c|c|c|}
\hline Problems Encountered & Frequency & Percentage \\
\hline Stealing of fishing gear and crafts & $226 *$ & 89.70 \\
\hline Conflicts & $246 *$ & 97.60 \\
\hline Social amenities & $240 *$ & 95.20 \\
\hline High cost of fishing materials (gear \& crafts) & $247 *$ & 98.00 \\
\hline Over fishing & 212 & 84.10 \\
\hline Lack of other social amenities & 22 & 8.70 \\
\hline Erosion & 10 & 4.00 \\
\hline Overpopulation & 3 & 1.20 \\
\hline Government assistance & 3 & 1.20 \\
\hline \multicolumn{3}{|l|}{ Problems } \\
\hline \multicolumn{3}{|l|}{$\begin{array}{l}\text { Problems encountered in relation to access to and } \\
\text { service of radio agricultural programme } \\
\text { "filin Mainoma". }\end{array}$} \\
\hline Language barrier & 29 & 11.60 \\
\hline Inconvenient time of broadcasting & 71 & 28.20 \\
\hline Detail enough & 237 & 94.00 \\
\hline Not in line with fish practices & 88 & 34.10 \\
\hline Network or Signal problems & 69 & 27.40 \\
\hline
\end{tabular}

* Multiple responses

Table 4 Result of Chi Square Analysis of Association between Respondent's Socio Demographic Characteristic and their Perception of Radio Agricultural Program "Filin Mainoma"

\begin{tabular}{lllll}
\hline Variables & $\chi^{2}$ & Df & P & Decision* \\
\hline Sex & 78.70 & 1 & 0.05 & $\mathrm{~S}$ \\
Educational level & 2.41 & 4 & 0.05 & $\mathrm{~S}$ \\
Religion & 18.30 & 2 & 1.05 & $\mathrm{NS}$ \\
Membership & 1.31 & 2 & 0.05 & $\mathrm{~S}$ \\
Major occupation & 40.90 & 1 & 0.05 & $\mathrm{~S}$
\end{tabular}

\footnotetext{
*Significance level, $\mathrm{P}<0.05 \quad \mathrm{NS}=$ Not Significant $\quad \mathrm{S}=$ Significant
} 
Table 5 Correlation analysis of their relationship between of the respondents Socio demography characteristic and their perception of radio agricultural programmes "filin mainoma,"

\begin{tabular}{llll}
\hline Variables & $\mathrm{r}$ & $\mathrm{P}$ & Decision \\
\hline Age & -0.08 & 0.18 & $\mathrm{NS}$ \\
Household size & 0.21 & 0.00 & $\mathrm{~S}$ \\
Year of membership & 0.24 & 0.00 & $\mathrm{~S}$ \\
Year of experience & 0.10 & 0.01 & $\mathrm{~S}$ \\
\hline
\end{tabular}

Source: field survey, 2011

*Significance level, $\mathrm{P}<0.05$

NS $=$ Not Significant

$\mathrm{S}=$ Significant

Table 6 Result of Pearson Moment Correlation Analysis of Respondents Constraints and their Perception of Radio Agricultural Program "Filin Mainoma"

\begin{tabular}{lccl}
\hline Variable & $\mathrm{r}$ & $\mathrm{P}$ & Decision \\
Constraint & 0.13 & 0.05 & $\mathrm{~S}$ \\
\hline *Significance level, $\mathrm{P}<0.05$ & $\mathrm{NS}=$ Not Significant & \\
source: field survey, 2011 & $\mathrm{~S}=$ Significant & \\
$<0.05=\mathrm{S}$ & & \\
$>0.05=\mathrm{NS}$ & &
\end{tabular}

